\title{
Cerebral aneurysms: current anaesthetic management and future horizons
}

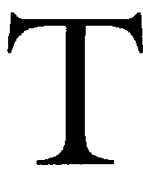

HE management of patients with intracranial vascular malformations has evolved considerably in the past $10-15$ yr. Anaesthetic management has also undergone significant evolution. This review will address some specific areas of this evolution and focus on the two most common lesions treated surgically; cerebral aneurysms and arteriovenous malformations (AVMs).

\section{Non-pharmacological cerebral protection}

The goals of a modern neuroanaesthetic should not solely revolve around provision of pharmacological brain protective therapy. There are a number of basic considerations that will maximise non-pharmacological cerebral protection (see the table shown below). Protective efforts are aimed towards two general types of damage: neurosurgical (anatomical) and anaesthetic (physiological) trespass. Possible mechanisms of injury from the neurosurgeon include brain retraction, direct vascular injury (ischaemia, thrombosis, venous occlusion) and mechanical disruption of neuronal tissue or white matter tracts. Anaesthetic injury may result from systemic hypo- or hypertension, decreased $\mathrm{O}_{2}$ content, hypoosmolarity or hyperglycaemia. It must be stressed that mechanisms of damage are interactive. For example, trivial amounts of brain retraction coupled with modest reduction of systemic blood pressure may have

TABLE Non-pharmacological cerebral protection

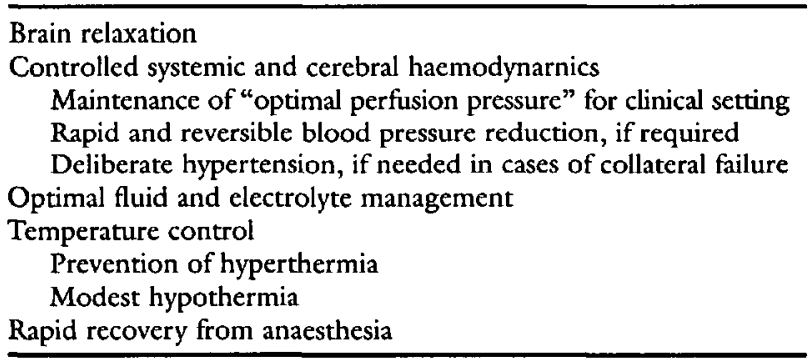

pronounced synergistic effects on emergence or neurological outcome.

Management goals should include providing a relaxed brain, controlled systemic and cerebral haemodynamics, maintenance of isotonicity and euglycaemia, temperature control and a controlled emergence from anaesthesia.

\section{Brain relaxation}

Adequate brain relaxation begins with good head positioning to promote intracranial venous drainage. The least amount of flexion and rotation necessary for the operative approach should be planned with the surgeon. Careful positioning of the head may also prevent post-operative tongue swelling, a rare but morbid occurrence. A rule of thumb might be given as "two fingerbreadths per $70 \mathrm{~kg}$ " between the mandible and clavicle (not the sternum) after the head is positioned in rigid-pin fixation. The head of the table should be positioned to prevent venous engorgement.

Cerebral spinal fluid removal is an effective means of brain relaxation, obtained by direct lumbar puncture or ventricular drainage. The most important consideration for anaesthetic choice intraoperatively is the avoidance of cerebral vasodilators. Modest hypocapnia should be used sparingly as an adjunct to brain relaxation, but levels $<30 \mathrm{mmHg}$ should have a specific indication. ${ }^{1}$ Diuretic therapy with mannitol and/or furosemide is widely applied. Mannitol infusion may be delayed until after removal of bone flap or aural reflection because of concerns of tearing of bridging veins, a potential increase in cerebral blood volume and flow or a rapid decrease in intracranial pressure (ICP). It should be noted that although the onset of action of mannitol is within five minutes, the peak effect occurs after $45 \mathrm{~min}$. The central haemodynamic consequences of the rapid administration of hypertonic mannitol should be considered in patients with impaired cardiac function. 


\section{Controlled systemic and cerebral haemodynamics}

Fluid restriction was a time-honoured means of guarding against brain swelling in the neurosurgical patient. Adequate intravascular volume to maintain stable systemic haemodynamics, especially with the application of induced hypotension, may require liberal fluid administration. Recent evidence reconciles these two apparently divergent goals (the influence of serum tonicity on fluid movement into the brain is discussed below).

Control of cerebral haemodynamics begins with control of systemic arterial pressure, which in turn is predicated on adequate cardiac preload (euvolaemia). Iatrogenic dehydration, as practised in years past, has no place in modern neurosurgical practice. Indeed, in the setting of aneurysmal subarachnoid haemorrhage $(\mathrm{SAH})$, it is deleterious. During manipulation of the intracranial contents or their vascular supply, the anaesthetist should strive to maintain the "optimal cerebral perfusion pressure," i.e., the highest clinically acceptable blood pressure for the particular clinical circumstance. Brain relaxation is probably also served by maintenance of a normal arterial pressure. Cerebral blood volume is kept to a minimum by appropriate autoregulatory vasoconstriction. ${ }^{2}$

\section{Fluid and electrolyte management}

There is a convincing body of evidence that it is tonicity of replacement therapy, not oncotic pressure, that is the primary determinant of water movement into both normal and damaged brain. ${ }^{3}$ Even mildly hypotonic fluids such as lactated Ringer's solution, if given in sufficient quantity, may aggravate brain swelling more than do isotonic crystalloids or colloids. Isotonic fluid replacement with either blood, saline or hetastarch after forebrain ischaemia in the rat appears to yield similar results in terms of cerebral oedema formation. ${ }^{4}$ The subject is not settled yet because a recent study suggested some incremental improvement in outcome after cerebral ischaemia when colloid was used instead of crystalloid (J. Drummond, unpublished data). The most important point is that fluid should never be withheld at the expense of a stable cardiovascular status. Serum osmolarity can be easily monitored if large volumes of crystalloid are needed.

The choice of colloids is not clear. Although hetastarch has been implicated as a cause of coagulation disorders, this is probably not important for volumes less than one litre used intraoperatively. Cost is the primary concern when choosing between hetastarch and human serum albumin. Postoperatively, hetastarch use is more controversial. ${ }^{5}$

There is considerable evidence that glucose aggravates cerebral injury. ${ }^{6}$ Routine perioperative steroids may cause some degree of hyperglycaemia. In the absence of clear guidelines, the most rational approach is to avoid glucose-containing fluids, unless there is a specific indication. One such indication would be a diabetic patient receiving insulin therapy. In this case, "tight" rather than "loose" control of serum glucose seems reasonable; it is probably not worth risking hypoglycaemia in an anaesthetised patient for any presumptive protective effect of lowering a mildly elevated glucose level.

\section{Temperature control}

Mild hypothermia (with core temperature decreases as little as $1.5-3^{\circ} \mathrm{C}$ ) confers dramatic cerebral protection against ischaemic insult in animal models. ${ }^{7}$ This protective effect is greater than what would be expected from metabolic suppression alone and may be related to a decrease in excitatory neurotransmitter release from ischaemic cells. ${ }^{8}$ Hypothermia appears to play a more significant role in determining outcome from ischaemic insult than choice of anaesthetic agents. ${ }^{9}$ Recent investigations reveal that anaesthetised patients can be easily cooled to the cerebroprotective range $\left(33-34^{\circ} \mathrm{C}\right.$ ), although complete intraoperative rewarming may be difficult to achieve. ${ }^{10}$ Even mild degrees of hypothermia are not without potential risk. Passive rewarming is associated with peripheral vasoconstriction, shivering, and subsequent increases in oxygen consumption and myocardial work. Drug metabolism is decreased, prolonging the effect of even short acting anaesthetic drugs. Postoperative hypothermia $\left(<35^{\circ} \mathrm{C}\right)$ is complicated by increased rates of myocardial ischaemia, angina, and arterial hypoxaemia in populations at risk for coronary artery disease. ${ }^{11}$ Moderate hypothermia $\left(<33^{\circ} \mathrm{C}\right)$ has other well documented potential effects, including increased susceptibility to infection, cardiac arrhythmias, hypocoagulability, thrombocytopenia, impaired platelet aggregation, and activation of fibrinolysis, all of which reverse with rewarming. ${ }^{10,11}$ It is unclear whether the potential benefits of cerebral protection gained from mild hypothermia and partial rewarming are offset by the systemic physiological stress induced, particularly if shivering occurs upon emergence. Intraoperative safety and efficacy studies are currently underway, and preliminary trials of mild hypothermia for head trauma victims appear promising. ${ }^{12}$

The induction of general anaesthesia results in an obligatory core temperature decrease as peripheral vasodilatation redistributes heat to the periphery. Rather than struggling to maintain normothermia, we currently believe that this temperature reduction $\left(34-35^{\circ} \mathrm{C}\right)$ should be tolerated until closure is imminent and only then should active rewarming with water blankets and convec- 
tive devices begin. Better strategies will be needed to cool more effectively and, especially, rewarm patients.

Postoperative hyperthermia may be detrimental ${ }^{13}$ and even exacerbated by mild intraoperative induced hypothermia. ${ }^{10}$ Therefore, careful attention should be paid to control of patient temperature in the ICU.

\section{Rapid emergence from anaesthesia}

Rapid return of consciousness (appropriate to the baseline level) is crucial and provides the means for immediate neurological evaluation. In case of a malpositioned clip or inadvertent sacrifice of an artery or vein subserving normal brain, early detection may facilitate timely intervention and may prevent a poor outcome.

Delayed awakening may not be solely due to residual anaesthetic. The intraoperative use of deliberate hypotension or hypothermia, excessive retractor pressure and the patient's baseline neurological status may be synergistic factors.

\section{Specific considerations for aneurysm clipping Difference between AVMs and aneurysms}

The anaesthetist should be aware of several important differences between aneurysms and AVMs. Approximately $10 \%$ of patients with AVMs also harbour intracranial aneurysms. Some of these aneurysms are "flow-related," and felt to be formed by the high shear stresses imposed by high flows through the parent artery supplying the fistula. Note that the converse is not true; the incidence of AVMs in aneurysm patients is probably much closer to the incidence of AVMs in the general population. Intracerebral haemorrhage (ICH) from aneurysms is usually associated with $\mathrm{SAH}$, whereas AVMs more commonly bleed into the ventricle or into parenchyma. This probably explains why the occurrence of vasospasm is uncommon after AVM haemorrhage compared to intracerebral aneurysm. In AVM patients spontaneous haemorrhage during the perioperative period as a result of an uncontrolled increase in systemic blood pressure is probably less likely than in a patient with a ruptured aneurysm. ${ }^{14}$ The high flow through the fistula induces arterial hypotension in the feeding vessels and this hypotension seems to act as a "buffer" to any changes in systemic pressure which, if directly transmitted to the abnormal vessels of the nidus, might result in rupture. ${ }^{15}$

\section{Preoperative considerations}

Subarachnoid Haemorrhage (SAH) can result in an assortment of serious medical problems, including hypertension, cardiac dysfunction, pneumonia, pulmonary aspiration, pulmonary oedema, gastrointestinal bleeding, deep vein thrombosis, syndrome of inappropriate anti-diuretic hormone (SIADH), cerebral salt-wasting syndrome, electrolyte imbalances, and glucose intolerance. In those centres that emphasise early surgical intervention in SAH to prevent rebleeding and facilitate vasospasm prophylaxis, medical status may not be optimal in many cases.

Cardiac abnormalities are particularly important. A wide variety of ECG changes in up to $50-80 \%$ of patients has been reported. ${ }^{14,16}$ Changes can appear early in the course and weeks. They include conduction disturbances, myocarditis and/or myocardial ischaemia, dysrhythmias and left ventricular (LV) failure. Left ventricular dysfunction generally improves over time as opposed to an acute myocardial infarction which may extend and worsen LV function. However the differentiation between SAH-associated LV dysfunction and myocardial ischaemia or infarction can be challenging. Echocardiographic abnormalities in patients with SAH are more likely to be correlated to poor neurological outcome than to a poor cardiovascular outcome. ${ }^{17}$

Important drug-drug interactions include effects on blood pressure and potentiation of muscle relaxants and volatile anaesthetics in patients receiving calcium channel blockers. ${ }^{18}$ Anticonvulsants, if administered for more than a week, induce resistance to nondepolarising neuromuscular blockade. ${ }^{19}$ Patients receiving antifibrinolytic drugs may have vascular access problems, a propensity to develop deep venous thrombosis and a higher incidence of vasospasm and hydrocephalus. $\mathrm{H}_{2}$-receptor blocking agents, particularly cimetidine, will delay the elimination of several anaesthetics and other drugs metabolised by the liver. Glucocorticosteroids may contribute to hyperglycaemia, hypertension, gastrointestinal bleeding, electrolyte imbalance and inhibition of the hypothalamic-pituitary adrenal axis.

The difference between the systemic arterial pressure and the ICP is the transmural pressure across the aneurysmal wall. Acute increases in transmural pressure, either by acutely increasing arterial pressure or decreasing ICP, may predispose to aneurysm rerupture. Extreme hypertension in the pre-operative period must be treated very cautiously, as it may be necessary to provide adequate cerebral perfusion. If it must be treated, gentle titration of an agent such as labetalol, a combined alpha- and beta-adrenergic receptor antagonist, may be indicated. Labetolol appears to have no effect on cerebral blood flow..$^{20}$ An alternative is the calciumchannel blocker nicardipine. ${ }^{21}$

Patients with altered sensorium should probably not receive anxiolytic premedication, but better grade patients can be considered for treatment with a small dose of a benzodiazapine. 


\section{Induction of anaesthesia}

Our practice includes monitoring all patients scheduled for craniotomy employing pulse oximeter, 5-lead ECG, capnograph, temperature probe, bladder catheter, peripheral nerve stimulator, and direct transduction of arterial pressure, usually from the radial artery.

Patients may have received prophylactic measures against vasospasm, including calcium-channel blocker therapy and hypertensive hypervolaemic haemodilution (HHH) therapy. ${ }^{22}$ Therefore, intravascular volume status is important to monitor. It is important to point out that there is no convincing evidence that increasing cardiac output directly improves cerebral blood flow $(\mathrm{CBF})$, as long as cerebral perfusion pressure (CPP) is adequate ${ }^{23}$ It is the pressure gradient across a vascular bed and its resistance that determine capillary flow and tissue perfusion. In chronic congestive heart failure, treating the low output state probably improves CBF by decreasing elevated central and, therefore, cerebral venous pressure. ${ }^{24}$ Furthermore, low output states can aggravate cerebral ischaemia. Activation of the sympathetic nervous system increases cerebrovascular resistance by constriction of proximal conductance arteries. ${ }^{25}$

Nevertheless, maintaining a relatively high intravascular volume (volume loading) is, compared with historical controls, associated with a better outcome. ${ }^{26}$ Central vascular pressure monitoring may be of use in patients who have compromised cardiovascular status or in those with a poor clinical grade. Volume loading may be used with inotropes or drugs which increase afterload. Monitoring of cardiac filling pressures may minimise complications such as fluid overload, dilutional hyponatraemia, exacerbation of cerebral oedema, congestive heart failure and pulmonary oedema.

There is no clear consensus on the use of electrophysiological monitors such as BEG and evoked potentials. In either deliberate hypotension or temporary arterial occlusion, their use is well justified. In addition, EEG can be used to titrate drugs such as thiopentone to the clinically-convenient endpoint of burst-suppression. However, burst-suppression should not be taken to be indicative of a "maximal protective dose" of such drugs.

Abrupt hypertension during induction may predispose to rebleeding. Rupture during induction and tracheal intubation has been reported to occur in $\approx 1-2 \%$ of patients. ${ }^{27}$ Rerupture during anaesthetic induction is associated with a markedly poorer prognosis than intraoperative rupture, ${ }^{27-29}$ perhaps due to limited ability of fresh haemorrhage to spread because of the presence of adhesions and pre-existing clot. Prolonged hypotension should be avoided in any brain-injured patient unless the risk is balanced against the benefit of gaining access to the neck of the aneurysm during clipping.

The choice of muscle relaxant to secure the airway must be based on airway considerations. Succinylcholine is contraindicated in patients with recent or progressive motor deficits; if used, increases in ICP may be blunted with pre-curarisation. Generally, we prefer to use nondepolarising drugs such as vecuronium.

There is no compelling evidence that the choice of induction agent offers an advantage in terms of cerebral protection and its choice should be based on systemic haemodynamic considerations.

Rapid, profound hyperventilation can decrease ICP with a closed skull and may increase transmural pressure across the aneurysm wall. Because hypocapniainduced cerebral vasoconstriction may threaten areas where perfusion pressure is already near the ischaemic threshold, a $\mathrm{PaCO}_{2}$ target of the mid-30s seems reasonable, unless there is a specific problem with brain relaxation or exposure.

\section{Anaesthesia maintenance}

There is no clearly superior technique for maintenance of anaesthesia. The choice of agent should be based on the goals described in the first section. High inspired concentrations have the potential to cause brain swelling. If brain relaxation becomes a problem, this should always be considered as a contributory cause. Low inspired concentrations of potent agents should not affect the interpretability of the EEG or evoked potentials. Use of agents with which the anaesthetist is most familiar to achieve the goals of nonpharmacological cerebral protection is probably the most rational approach to choice of specific agents. In principle, drugs with short half-lives and rapid dissipation of effect are desirable to allow titration of effect and rapid emergence.

Newer agents include desflurane, which is relatively insoluble compared with older agents, ${ }^{30}$ but may be associated with significant increases in blood pressure during induction..$^{31}$ Propofol can also be used in a total intravenous technique. ${ }^{22}$ Remifentanil, a new opioid with a very short half-life independent of the duration of infusion, has recently been introduced into clinical practice and is currently being evaluated for neuroanaesthesia. ${ }^{32,33}$ Coughing or patient movement can have devastating effects during microsurgery; vigilance for muscle relaxation is mandatory. In rare cases spontaneous respiration is being used to monitor brainstem function; ${ }^{34}$ however, mechanical ventilation is the rule.

When the aneurysm is being approached, and prior to the application of the clip, measures may be taken 
to soften the dome of the aneurysm so that the surgeon can gently manipulate it with a lower risk of rupture. In order to reduce the pressure within the dome of the aneurysm, either the systemic arterial pressure may be reduced or the surgeon may apply a temporary clip across the vessel feeding the aneurysm.

Until recently, deliberate controlled hypotension was in widespread use during aneurysm clipping and was considered a major advance in neurosurgery which improved outcome in the surgical management of intracranial aneurysms. ${ }^{35}$ Concerns regarding the risk of perioperative cerebral ischaemia and infarction, however, have led to the abandonment of this technique in many centres. ${ }^{36}$ Even so, with meticulous attention to detail and the application of modern cardiovascular and neurophysiological monitoring techniques, hypotension may still be indicated in selected patients. A recent survey of 41 North American aneurysm centres revealed that this technique is still utilised by approximately $48 \%$ of neuroanaesthetists. ${ }^{37}$

Although deliberate hypertension has been extensively reported during temporary vascular occlusion for aneurysm clipping, ${ }^{38-42}$ the data are, again, largely anecdotal or observational.

Recently, temporary occlusion of the aneurysm's parent vessel has become the more commonly used method to lower the pressure stress within the aneurysm. Temporary vascular occlusion for aneurysm clipping is far more likely to be distal to the circle of Willis. Therefore, the chance of adequate collateral perfusion is therefore more limited.

With temporary clipping, blood pressure is generally empirically kept at least $10-20 \%$ above awake levels in order to reduce the likelihood of collateral circulatory failure. The alpha-adrenergic agonist phenylephrine is the most commonly used agent for this purpose. Temporary occlusion may be associated with cerebral ischaemia and infarction, despite maintenance of augmented collateral perfusion pressure. ${ }^{43}$

The most commonly used (and best justified) neuroprotective anaesthetic is thiopentone. The case for protection from ischaemia is much weaker for propofol and etomidate. Just before application of the temporary clip, thiopentone may be titrated to a deep burst suppression or isoelectric-pattern on the EEG. Limiting the dose to burst suppression may preserve the ability to detect cerebral ischaemia on the basis of progressive EEG changes. Although the utility of EEG analysis during aneurysm surgery has been challenged on the basis of poor sensitivity, the number of false negatives may be reduced when cortical EEG electrodes which survey the area at greatest risk are used..$^{40}$ Alternatively, evoked potentials may be used for detection of ischaemia. ${ }^{44}$
Thiopentone in large doses has been thought to be a strong myocardial depressant. Recent studies have shown, however, that myocardial function and blood pressure are well maintained when the patient is well hydrated.$^{45}$ Even so, in patients with significant myocardial dysfunction or severe ischaemic heart disease etomidate may be the agent of choice.

Once the aneurysm is clipped, more aggressive therapy to prevent or treat vasospasm may be instituted: intravascular volume is increased, blood pressure is raised to the high normal range by intravascular volume loading and/or by the administration of vasopressor agents. Blood loss is generally not replaced unless the decrease in haematocrit threatens systemic oxygen delivery.

\section{Disaster}

Whether or not deliberate hypotension is planned, hypotensive agents should be readily available in case of intraoperative aneurysmal rupture. The prognosis following intraoperative bleeding appears to be related to the speed with which haemostasis is achieved. Mean arterial pressure may need to be rapidly decreased to $40-50 \mathrm{mmHg}$ in order to decrease bleeding and facilitate surgical exposure so as to gain control of the aneurysm and its parent vessel.

Most surgeons routinely obtain what is termed "proximal control" of the parent artery of the aneurysm, either in the operative field or by means of a cutdown on the cervical internal carotid artery. Notwithstanding, it may be necessary to compress the ipsilateral common carotid artery manually in certain instances. Thus, it is advisable to assure that this anatomical region is accessible after positioning the patient.

During uncontrolled bleeding the surgeons may be forced to place clips blindly in an attempt to stem haemorrhage. In this event, barbiturate therapy may be indicated and could be used as a means of (or an adjunct to) the induction of mild or moderate temporary arterial blood pressure reduction until bleeding is brought under control. However, the clinician should use whatever means with which he or she is comfortable and adept to reduce blood pressure expeditiously as demanded by the clinical situation.

\section{Endovascular treatment Overpiew}

Abnormalities of the cerebrovascular system are being treated with ever-increasing frequency by means of an endovascular approach. Interventional Neuroradiology (INR), may be broadly defined as treatment of central nervous system (CNS) disease by endovascular access for the purpose of delivering therapeutic agents, including both drugs and devices. ${ }^{46}$ This specialty is a hybrid 
of traditional neurosurgery and neuroradiology, with certain overlaps with aspects of head-and-neck surgery.

The three primary functions of the anaesthetist in the interventional suite are (1) provision of a physiologically stable and immobile patient, (2) manipulation of the systemic blood pressure as dictated by the needs of the procedure, and (3) emergency care of catastrophic complications.

Many of the risks encountered in this newer arena are the same as during traditional operative neurosurgery (e.g., aneurysmal rupture or cerebral ischaemia from vascular occlusion) and the anaesthetist's manipulation of systemic and cerebral haemodynamics (e.g., deliberate hypotension or hypertension) is also the same. Although many of the risks and responses are, for the most part, conceptually the same, there are many important differences in the working environment.

Historically, the pioneers in INR provided light intravenous sedation with rudimentary monitoring for their adult patients. However, anaesthesia coverage in many centres has become the standard of care. As the complexity of procedures and breadth of patient populations expands, the distinction between the interventional angiography suite and the operating room will blur. For a detailed discussion of indications and experience, the reader is referred elsewhere. ${ }^{47}$

\section{Treatment of cerebral aneurysms}

Most aneurysms can be safely obliterated surgically with preservation of the parent vessel. However, difficulties in the management of certain types of aneurysms remain, such as giant or fusiform aneurysms. The two basic approaches for INR therapy are occlusion of proximal parent arteries and obliteration of the aneurysmal sac.

For some giant aneurysms, cervical carotid balloon ligation may be performed with or without subsequent extracranial-to-intracranial bypass. A trial test-occlusion protocol with physiological monitoring may be useful in predicting which patients have borderline cerebrovascular reserve. ${ }^{48}$

The aneurysmal sac may be obliterated by use of coils and balloons. The newest form of treatment for aneurysms is the Guglielmi Detachable Coil (GDC). ${ }^{49}$ This is a curlicue type of platinum coil of various lengths. It is attached to a stainless steel guide wire. The coil is passed through a superselective catheter into the aneurysmal sac and then detached by passing an electric current through the guide wire, which causes the stainless steel portion to detach from the platinum coil by electrolysis, leaving the coil curled up in the sac. Because of a lesser need to follow the neurologic examination, these cases are frequently done under general anaesthesia with tracheal intubation.
The anaesthetist should be prepared for aneurysmal rupture and acute SAH at all times, either from spontaneous rupture of a leaky sac or direct violation of the aneurysm wall during vascular manipulation. At the present time there is not the same degree of certainty that the lesion has been completely removed from the circulation after coil ablation of the aneurysm as there is with application of a surgical clip. There may be areas of the dome that are still in contact with the arterial blood column. Therefore, careful attention to post-procedure blood pressure control is mandatory.

Treatment of cerebral vasospasm from aneurysmal $S A H$ Symptomatic vasospasm refractory to deliberate hypertension and intravascular volume expansion may, in certain cases, be amenable to endovascular treatment. In the large proximal conductance vessels (usually internal carotid, middle or anterior cerebral arteries), balloon angioplasty may be considered. ${ }^{50}$ Angioplasty is generally reserved for patients who have already had the symptomatic lesion surgically clipped (for fear of rerupture) and attempts to medically manage symptomatic ischaemia have failed.

Endovascular treatment is best done early in the course of symptomatic ischaemia in order to prevent transformation of a bland infarct into a haemorrhagic one. A balloon catheter is guided under fluoroscopy into the spastic segment and inflated to mechanically distend the constricted area.

Another approach to vasospasm is to use a pharmacological means to dilate the vasospastic segment. Superselective intraarterial administration of papaverine has proven successful in certain patients. ${ }^{51}$

\section{Acknowledgments}

The author thanks Joyce Ouchi, E. Ornstein and Z. Shenkman for assistance in preparation of this manuscript.

\section{References}

1 Young $W L$, Ravussin PA. Is there still a place for routine deep hypocapnia for intracranial surgery? (French) Ann Fr Anesth Reanim 1995; 14: 70-6.

2 Rosner MJ. Cerebral perfusion pressure: link between intracranial pressure and systemic circulation. In: Wood $\mathrm{JH}$ (Ed.). Cerebral Blood Flow: Physiologic and Clinical Aspects. New York: McGraw-Hill Book Company, 1987: 425-48.

3 Zornow MH, Todd MM, Moore SS. The acute cerebral effects of changes in plasma osmolality and oncotic pressure. Anesthesiology 1987; 67: 936-41. 
4 Warner DS, Boebland LA. The effects of iso-osmolal hemodilution on post-ischemic brain water content in the rat. Anesthesiology 1988; 68: 86-91.b

5 Trumble ER, Muizelaar JP, Myseros JS, Choi SC, Warren $B B$. Coagulopathy with the use of hetastarch in the treatment of vasospasm. J Neurosurg 1995; 82: 44-7.

6 Lanier WL. Glucose management during cardiopulmonary bypass: cardiovascular and neurologic implications (Editorial). Anesth Analg 1991; 72: 423-7.

7 Busto $R$, Dietrich WD, Globus $M Y-T$, Valdes 1 , Scheinberg, Ginsberg MD. Small differences in intraischemic brain temperature critically determine the extent of ischemic neuronal injury. J Cereb Blood Flow Metab 1987; 7: 729-38.

8 Busto R, Dietrich WD, Globus MT-T, Ginsberg MD. The importance of brain temperature in cerebral ischemic injury. Stroke 1989; 20: 1113-4.

9 Sano T, Drummond JC, Patel PM, Grafe MR, Watson $J C$, Cole DJ. A comparison of the cerebral protective effects of isoflurane and mild hypothermia in a model of incomplete forebrain ischemia in the rat. Anesthesiology 1992; 76: 221-8.

10 Baker KZ, Young WL, Stone JG, Kader A, Baker CJ, Solomon $R A$. Deliberate mild intraoperative hypothermia for craniotomy. Anesthesiology 1994; 81: 361-7.

11 Frank SM, Beattie C, Christopherson R, et al. Unintentional hypothermia is associated with postoperative myocardial ischemia. Anesthesiology 1993; 78: 468-76.

12 Marion DW, Obrist WD, Carlier PM, Penrod LE, Darby JM. The use of moderate therapeutic hypothermia for patients with severe head injuries: a preliminary report. J Neurosurg 1993; 79: 354-62.

13 Chen $H$, Chopp $M$. Effect of mild hyperthermia on the ischemic infarct volume after middle cerebral artery occlusion in the rat. Neurology 1991; 41: 1133-5.

14 Andreoli $A$, diPasquale $G$, Pinelli $G$, Grazi $P$, Tognetti $F$, Testa $C$. Subarachnoid hemorrhage: frequency and severity of cardiac arrhythmias. A survey of 70 cases studied in the acute phase. Stroke 1987; 18: 558-64.

15 Toung WL, KaderA, Pile-Spellman J, Ornstein E, Stein $B M$, Columbia University AVM Study Project. Arteriovenous malformation draining vein physiology and determinants of transnidal pressure gradients. Neurosurgery 1994; 35: 389-96.

16 Mayer SA, LiMandri $G$, Sherman $D$, et al. Electrocardiographic markers of abnormal left ventricular wall motion in acute subarachnoid hemorrhage. J Neurosurg 1995; 83: 889-96.

17 Davies KR, Gelb AW, Manninen PH, Boughner DR, Bisnaire $D$. Cardiac function in aneurysmal subarachnoid haemorrhage: a study of electrocardiographic and echocardiographic abnormalities. Br J Anaesth 1991; 67: 58-63.
18 Warner DS, Sokoll MD, Maktabi M, Godersky JC, Adams HP. Nicardipine HCI: clinical experience in patients undergoing anaesthesia for intracranial aneurysm clipping. Can J Anaesth 1989; 36: 219-23.

19 Ornstein E, Matteo RS, Schwartz AK, Silverberg PA, Young WL, Diaz $J$. The effect of phenytoin on the magnitude and duration of neuromuscular block following atracurium or vecuronium. Anesthesiology 1987; 67: 191-6.

20 Schroeder T, Schierbeck J, Howardy P, Knudsen L, Skafte-Holm P, Gefke K. Effect of labetalol on cerebral blood flow and middle cerebral arterial flow velocity in healthy volunteers. Neurol Res 1991; 13: 10-2.

21 Abe $K$, Inagaki $Y$, Imanaga $H$. Effect of nicardipine on the blood flow velocity in the vessel near a cerebral aneurysm of the internal carotid artery during cerebral aneurysm surgery: its therapeutic use for intra-operative hypertension. Eur J Anaesthesiol 1993; 10: 287-9.

22 Ravussin $P$, de Tribolet $N$. Total intravenous anesthesia with propofol for burst suppression in cerebral aneurysm surgery: preliminary report of 42 patients. Neurosurgery $1993 ; 32: 236-40$.

23 Bouma GJ, Muizelaar JP. Relationship between cardiac output and cerebral blood flow in patients with intact and with impaired autoregulation. J Neurosurg 1990; 73: 368-74.

24 Paulson $O B$, Jarden JO, Vorstrup S, Holm S, Godtiredsen $J$. Effect of captopril on the cerebral circulation in chronic heart failure. Eur J Clin Invest 1986; 16: 124-32.

25 Paulson OB, Strandgaard S, Edvinsson L. Cerebral autoregulation. Cerebrovasc Brain Metab Rev 1990; 2: 161-92.

26 Kassell NF, Peerless SJ, Drake CG, Boarini DJ, Adams HP. Treatment of ischemic deficits from cerebral vasospasm with high dose barbiturate therapy. Neurosurgery 1980; 7: 593-7.

27 Batjer $H$, Samson $D$. Intraoperative aneurysmal rupture: incidence, outcome, and suggestions for surgical management. Neurosurgery 1986; 18: 701-7.

28 Schramm J, Cedzich C. Outcome and management of intraoperative aneurysm rupture. Surg Neurol 1993; 40: 26-30.

29 Tsementzis $S A$, Hitchcock ER. Outcome from "rescue clipping" of ruptured intracranial aneurysms during induction anaesthesia and endotracheal intubation. J Neurol Neurosurg Psychiatry 1985; 48: 160-3.

30 Ornstein E, Young WL, Fleischer LH, Ostaplovich N. Desflurane and isoflurane have similar effects on cerebral blood flow in patients with intracranial mass lesions. Anesthesiology 1993; 79: 498-502.

31 FleischerLH, Young WL, OrnsteinE, SmileyRS. Systemic hemodynamic changes of desflurane vs isoflurane during anesthetic induction. Anesthesiology 1992; 77: A334. 
32 Baker KZ, Ostapkopich $N$, Mack PF, Jackson T, Sisti MB, roung WL. Cerebral blood flow reactivity is similar during remifentanil $/ \mathrm{N}_{2} \mathrm{O}$ and fentany $/ \mathrm{N}_{2} \mathrm{O}$ anesthesia (Abstract \#702). J Neurosurg Anesth 1996; 8: 339.

33 Guy J, Hindman BJ, Baker KZ, et al. Comparison of remifentanil and fentanyl in patients undergong craniotomy for supratentorial space-occupying lesions. Anesthesiology 1997; 86: 514-23.

34 Manninen PH, Cuillerier DJ, Nantau WE, Gelb AW. Monitoring of brainstem function during vertebral basilar aneurysm surgery. The use of spontaneous ventilation. Anesthesiology 1992; 77: 681-5.

35 Wilson $C B$, Spetzler RF. Factors responsible for improved results in the surgical management of intracranial aneurysms and vascular malformations. Am J Surg 1977; 134: 33-8.

36 Drummond JC. Deliberate hypotension for intracranial aneurysm surgery: Changing practices (Letter). Can J Anaesth 1991; 38: 935-6.

37 Craen $R A$, Gelb $A W$, Eliasziw $M$, Lok P. Current anesthetic practices and use of brain protective therapies for cerebral aneurysm surgery at 41 North American centers. J Neurosurg Anesth 1994; 6: 303.

38 Ogilry CS, Rich C, Crowell RM. Mild hypothermia, mannitol, and induced hypertension for cerebral protection during temporary vessel occlusion in aneurysm surgery is safe and effective. J Neurosurg 1993; 78: 367A (Paper 837).

39 Wasnick JD, Conlay $L A$. Induced hypertension for cerebral aneurysm surgery in a patient with carotid occlusive disease. Anesth Analg 1990; 70: 331-3.

40 Young $W L$, Solomon $R A$, Pedley $T A$, et al. Direct cortical EEG monitoring during temporary vascular occlusion for cerebral aneurysm surgery. Anesthesiology 1989; 71: 794-9.

41 Buckland MR, Bather $H H$, Giesecke $A H$. Anesthesia for cerebral aneurysm surgery: Use of induced hypertension in patients with symptomatic vasospasm. Anesthesiology 1988; 69: 116-9.

42 Rosenwasser RH, Jimenez DF, Wending WW, Carlsson $C$. Routine use of etomidate and temporary vessel occlusion during aneurysm surgery. Neurol Res 1991; 13: 224-8.

43 Samson DS, Batber HH, Bowman G, et al. A clinical study of the parameters and effects of temporary arterial occlusion in the management of intracranial aneurysms. Neurosurgery $1994 ; 22-9$.

44 Tanigachi M, Nadstawek J, Pechstein U, Schramm J. Total intravenous anesthesia for improvement of intraoperative monitoring of somatosensory evoked potentials during aneurysm surgery. Neurosurgery 1992; 31: 891-7.

45 Stone JO, Young WL, Marans ZS, et al. Cardiac performance preserved despite thiopental loading. Anesthesiology 1993; 79: 36-41.
46 Pile-Spellman J. Endovascular therapeutic neuroradiology. In: Taveras JM (Ed.). Neuroradiology, 3rd ed. Baltimore: Williams \& Wilkins, 1996: 1045-179.

47 roung WL, Pile-Spellman J. Anesthetic considerations forinterventional neuroradiology. Anesthesiology 1994; 80: 427-56.

48 Fox AJ, Vinuela F, Pelz DM, et al. Use of detachable balloons for proximal artery occlusion in the treatment of unclippable cerebral aneurysms. J Neurosurg 1987; 66: $40-6$.

49 Guglielmi G, Vinuela $F$, Duckwiler $G$, et al. Endovascular treatment of posterior circulation aneurysms by electrothrombosis using electrically detachable coils. J Neurosurg 1992; 77: 515-24.

50 Newell DW, Eskridge JM, Mayberg MR, Grady MS, Winn HR. Angioplasty for the treatment of symptomatic vasospasm following subarachnoid hemorrhage. J Neurosurg 1989; 71: 654-60.

51 Fogarty-Mack P, Pile-Spellman J, Hacein-Bey L, et al. Superselective intraarterial papaverine administration: effect on regional cerebral blood flow in patients with arteriovenous malformations. J Neurosurg 1996; 85: 395-402. 
William L. Young, MD

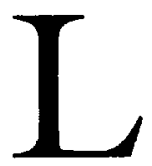

A prise en charge des patients avec malformations vasculaires intracrâniennes a beaucoup évolué au cours des 10-15 dernières années. $\mathrm{La}$ conduite anesthésique a aussi connu une évolution significative. Ce texte de revue s'occupera de certains aspects de cette évolution et l'attention principale sera mise sur les deux lésions les plus fréquentes en termes de traitement chirurgical : l'anévrysme et la malformation artérioveineuse (MAV).

\section{Protection cérébrale non-pharmacologique}

Les buts d'une neuroanesthésie moderne ne doivent pas seulement se limiter à apporter au cerveau un traitement pharmacologique protecteur. Il existe un certain nombre de considérations de base qui vont maximiser la protection cérébrale non-pharmacologique (Tableau). Les efforts de protection visent deux types généraux de dommages : les effractions neurochirurgicales (anatomiques) et les effractions anesthésiques (physiologiques). Les mécanismes possibles de lésion de la part du neurochirurgien incluent la rétraction du tissu cérébral, la lésion vasculaire directe (ischémie, thrombose, occlusion veineuse) et le dérangement mécanique du tissu neuronal ou des faisceaux de matière blanche. Les lésions d'origine anesthésiques peuvent provenir de l'hypo ou de l'hypertension systémique, d'une diminution du contenu en $\mathrm{O}_{2}$, de l'hypoosmolarité ou de l'hyperglycémie. Il faut insister sur le fait que les mécanismes responsables du dommage

\section{TABLEAU Protection cérébrale non-pharmacologique}

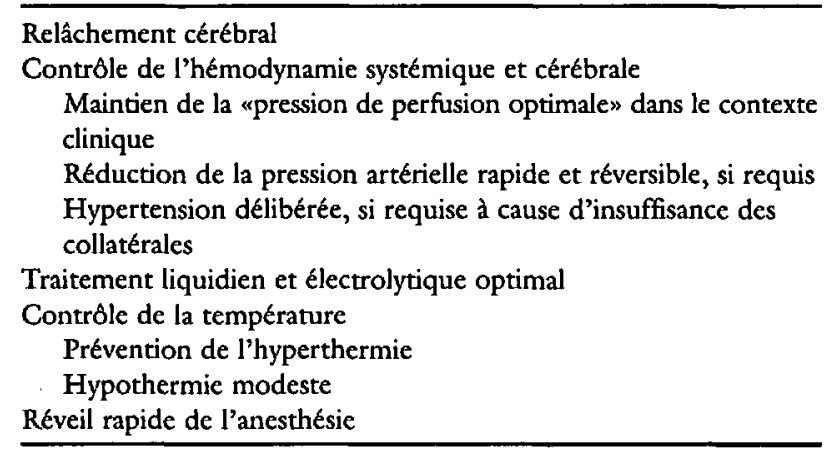

\section{Anévrysmes cérébraux : prise en charge anesthésique courante et horizons futurs}

nerveux sont interactifs. Par exemple, une rétraction cérébrale modeste couplée à une réduction modeste, elle aussi, de la pression artérielle systémique peut avoir des effets synergiques prononcés sur le réveil ou le devenir neurologique.

Les buts de la prise en charge devraient comprendre la production d'un cerveau relâché, une hémodynamie cérébrale et systémique sous contrôle, le maintien de l'isotonicité et de la normoglycémie, le contrôle de la température et un réveil contrôlé.

\section{Relâchement cérébral}

Un relâchement cérébral adéquat débute avec un bon positionnement de la tête pour favoriser le drainage veineux. Le plus faible degré de flexion et de rotation nécessaire à l'approche opératoire doit être planifié avec le neurochirurgien. Le positionnement attentif de la tête peut aussi prévenir le gonflement postopératoire de la langue, complication peu fréquente mais entraînant une morbidité significative. Empiriquement, la distance entre la mandibule et la clavicule (et non le sternum) après que la tête soit placée dans le système de fixation rigide avec pointes devrait être de $\ll 2$ travers de doigts par $70 \mathrm{~kg}$ ». La tête de la table doit être placée de façon à éviter la congestion veineuse.

Le drainage du LCR est une méthode efficace de relaxation du cerveau et est réalisé par ponction lombaire directe ou par drainage ventriculaire. La plus importante considération quant aux choix des anesthésiques en peropératoire est l'abstention de vasodilatateurs cérébraux. Une hypocapnie modeste devrait être utilisée avec modération comme ajout à la relaxation cérébrale, les niveaux inférieurs à $30 \mathrm{mmHg}$ étant réservés à des indications spécifiques. ${ }^{1}$ La thérapie diurétique avec mannitol et ou furosémide est largement utilisée. L'infusion de mannitol peut être retardée jusqu'après la crâniotomie ou l'ouverture de la dure-mère en raison de préoccupations concernant les déchirements veineux, concernant aussi une augmentation temporaire du volume ou du flot sanguin ou une baisse rapide de la pression intracrânienne (PIC). Il faut noter que même si le début d'action du mannitol se fait en 5 minutes, son pic d'action arrive 
à 45 minutes. Les conséquences hémodynamiques centrales de l'administration rapide du mannitol hypertonique doivent être prises en considération chez les patients avec une fonction cardiaque déficiente.

\section{Contrôle de l'bémodynamie systémique et cérébrale}

La restriction liquidienne a été le moyen classique de protéger le patient neurochirurgical de l'œdème cérébral. Le maintien d'un volume intravasculaire adéquat pour maintenir une hémodynamie systémique stable, spécialement avec l'utilisation de l'hypotension contrôlée, peut nécessiter l'administration généreuse de liquides. Des données récentes réconcilient ces deux buts en apparence divergents; l'influence de la tonicité sérique sur les mouvements de liquides dans le tissu cérébral est discutée plus loin dans le texte.

Le contrôle de l'hémodynamie cérébrale débute avec le contrôle de la pression artérielle systémique qui à son tour repose sur une précharge cardiaque adéquate (euvolémie). La déshydratation iatrogène, telle que pratiquée dans le passé, n'a plus sa place dans une pratique neurochirurgicale moderne. En outre, dans le contexte de l'hémorragie sous arachnoïdienne anévrysmale (HSA), cette pratique est délétère. Durant les manipulations du contenu intracrânien ou de son apport vasculaire, l'anesthésiste doit s'astreindre à maintenir la epression de perfusion cérébrale optimale» c'est-à-dire la pression sanguine la plus élevée cliniquement acceptable pour la circonstance clinique particulière. Le relâchement cérébral est probablement aussi favorisé par le maintien d'une pression artérielle normale. Le volume sanguin cérébral est maintenu à son minimum par l'autorégulation qui assure une vasoconstriction appropriée. ${ }^{2}$

\section{Contrôle des liquides et des électrolytes}

Il existe des données convaincantes que c'est la tonicité de la thérapie de remplacement, et non la pression oncotique, qui est le déterminant premier du mouvement de l'eau tant dans le cerveau normal que dans le cerveau endommagé. ${ }^{3}$ Même un liquide légèrement hypotonique comme le Ringer avec lactate, s'il est administré en quantité suffisante, peut aggraver l'oedème cérébral plus que des crystalloïdes isotoniques ou des colloïdes. Des remplacements isotoniques avec du sang, du salin $0,9 \%$ ou de l'hydroxyéthylamidon après ischémie du prosencéphale chez le rat semblent donner des résultats comparables en termes de formation d'œdème cérébral. ${ }^{4}$ Le sujet n'est pas clos puisqu'une étude récente suggère une amélioration dans le pronostic après ischémie cérébrale lorsque des colloïdes sont utilisés à la place des crystalloïdes (J. Drummond, données non publiées). Le point le plus important est qu'il ne faut jamais restreindre les liquides aux dépens d'un état cardiovasculaire sta- ble. L'osmolarité sérique peut facilement être monitorée si de grandes quantités de crystalloödes sont nécessaires.

Le choix des colloïdes n'est pas clair. Même si l'hydroxyéthylamidon a été impliqué comme cause de désordres de la coagulation, ceci n'est probablement pas important pour les volumes de moins de un litre utilisés en peropératoire. Le coût est la préoccupation première lorsqu'il faut choisir entre l'hydroxyéthylamidon et l'albumine humaine. En postopératoire, l'utilisation de l'hydroxyéthylamidon est plus controversé. ${ }^{5}$

Il y a beaucoup de preuves que le glucose aggrave les lésions cérébrales. ${ }^{6} \mathrm{~L}$ 'utilisation périopératoire routinière des stéroïdes peut causer un certain degré d'hyperglycémic. En l'absence de lignes directrices nettes, l'approche la plus rationnelle consiste à éviter les solutions contenant du glucose, à moins d'indication spécifique, comme un patient diabétique sous thérapie insulinique. Dans ce cas, il apparait raisonnable de préconiser un contrôle serré plutôt que lâche de la glycémie mais il n'est probablement pas sage de risquer une hypoglycémie sous anesthésie pour bénéficier d'un effet protectif présomptif de l'abaissement d'une glycémie légèrement élevée.

\section{Contrôle de la température}

L'hypothermie légère (abaissement de la température centrale de 1,5 à $3^{\circ} \mathrm{C}$ ) apporte une protection cérébrale dramatique contre le dommage ischémique dans les modèles animaux. ${ }^{7}$ Cet effet protecteur est plus grand que ce que l'on pourrait attendre de la réduction métabolique simple et est peut être en relation avec une diminution de la relâche des neurotransmetteurs excitatifs à partir des cellules ischémiques. ${ }^{8}$ L'hypothermie semble jouer un rôle plus significatif dans le devenir après insulte ischémique que le choix des agents anesthésiques. ${ }^{9}$ Des études récentes montrent que des patients anesthésiés peuvent facilement être refroidis dans la zone cérébroprotectrice $\left(33-34^{\circ} \mathrm{C}\right)$, même si le réchauffement intraopératoire complet peut être difficile par la suite. ${ }^{10}$ Cependant, même des degrés légers d'hypothermie ne sont pas dénués de risques. Le réchauffement passif est associé à de la vasoconstriction périphérique et à des frissons avec l'augmentation de la consommation d'oxygène et du travail cardiaque qu'ils entrainent, et le métabolisme des médicaments est diminué, prolongeant l'effet des médicaments anesthésiques même à courte action. L'hypothermie postopératoire $\left(<35^{\circ} \mathrm{C}\right)$ se complique de taux augmentés d'ischémie myocardique, d'angine et d'hypoxémie artérielle chez les populations à risque de maladie coronarienne. ${ }^{11} \mathrm{~L}$ 'hypothermie modérée $\left(<33^{\circ} \mathrm{C}\right)$ a d'autres effets potentiels bien documentés incluant la susceptibilité accrue aux infections, les arythmies cardiaques, 
l'hypocoagulabilité, la thrombocytopénie, l'agrégation plaquettaire déficiente et l'activation de la fibrinolyse, tous ces effets disparaissant avec le réchauffement. ${ }^{10,11}$ On ne sait pas de façon certaine si les bénéfices potentiels de protection cérébrale conférés par une hypothermie légère et un réchauffement partiel sont annulés par le stress physiologique provoqué, spécialement si des frissons surviennent au réveil. Des études peropératoires concernant l'efficacité et la sécurité sont actuellement en marche, et les essais préliminaires d'hypothermie légère pour les victimes de trauma crânien semblent prometteurs. ${ }^{12}$

L'induction de l'anesthésie générale entraîne une chute de la température centrale au moment où la vasodilatation périphérique redistribue la chaleur à la périphérie. Plutôt que de lutter pour maintenir la normothermie, on croit actuellement que cette réduction de température $\left(34-35^{\circ} \mathrm{C}\right)$ devrait être tolérée jusqu'à ce que la fermeture soit proche et qu'à ce moment seulement on devrait entreprendre le réchauffement actif avec matelas chauffants utilisant l'eau ou l'air pulsé. De meilleures stratégies seront nécessaires pour refroidir et réchauffer les patients de façon plus efficace.

L'hyperthermie postopératoire peut être préjudiciable $^{13}$ et peut être favorisée par une hypothermie peropératoire légère. ${ }^{10}$ Donc, il faut faire très attention au contrôle de la température des patients aux soins intensifs.

\section{Réveil rapide de l'anesthésie}

Un retour rapide à la conscience (en rapport avec l'état préexistant) est essentiel et permet une évaluation neurologique immédiate. Dans l'éventualité d'une pince mal placée ou du sacrifice non planifié d'une artère ou d'une veine desservant du parenchyme cérébral normal, un diagnostic précoce peut faciliter une intervention appropriée et prévenir un résultat désastreux.

Un réveil retardé peut ne pas être uniquement dû à une anesthésie résiduelle. L'utilisation peropératoire de l'hypotension ou de l'hypothermie délibérée, une pression excessive des rétracteurs et l'état de base du patient peuvent tous être des facteurs synergiques.

\section{Considération spécifiques pour \\ le clipping anévrysmal \\ Différence entre les $M A V$ et les anévrysmes}

L'anesthésiste doit être au courant de plusieurs différences importantes entre les malformations artérioveineuses (MAV) et les anévrysmes. Environ 10\% des patients porteurs de MAV sont aussi porteurs d'anévrysmes. Certains de ces anévrysmes sont en «relation avec le flot» dans la mesure où on pense qu'ils sont formés par les forces de cisaillement élevées produites par les flots élevés dans l'artère qui nourrit la fistule. A noter que l'inverse n'est pas vrai : l'incidence de MAV chez les patients porteurs d'anévrysmes est probablement proche de l'incidence de MAV dans la population générale. L'hémorragie intracérébrale à partir des anévrysmes est en général associée à une hémorragie sous-arachnoïdienne (HSA) alors que les MAV saignent plus souvent dans les ventricules ou dans le parenchyme. Ceci explique probablement pourquoi le vasospasme est rare après un saignement de MAV par rapport à celui d'un anévrysme intracérébral. Chez les patients porteurs d'une MAV, l'hémorragie spontanée durant la période périopératoire comme résultat d'une augmentation incontrôlée de la pression artérielle est probablement moins probable que chez un patient avec anévrysme rupturé. ${ }^{14}$ Le flot élevé dans la fistule produit une hypotension artérielle dans les vaisseaux nourriciers et cette hypotension semble agir comme un «tampon» face à tous les changements de la pression systémique qui, s'ils étaient transmis directement aux vaisseaux anormaux au coeur de la malformation, pourraient entrainer une rupture. ${ }^{15}$

\section{Considérations préopératoires}

L'hémorragie sous arachnoïdienne (HSA) peut entraîner une foule de problèmes médicaux sérieux tels que hypertension, dysfonction cardiaque, pneumonie, aspiration pulmonaire, œdème pulmonaire, saignement digestif, thrombose veineuse profonde, SIADH, syndrome de perte de sel d'origine cérébrale, débalancements électrolytiques et intolérance au glucose. Dans les centres qui préconisent une intervention chirurgicale précoce dans les HSA pour prévenir le resaignement et faciliter la prophylaxie contre le vasospasme, l'état médical du patient peut souvent ne pas être optimal.

Les anomalies cardiaques sont particulièrement importantes. Une grande variété de modifications de l'ECG ont été rapportées chez 50 à $80 \%$ des patients. ${ }^{14,16}$ Les changements peuvent apparaitre de façon précoce et persister durant des semaines; ils comprennent des anomalies de la conduction, des myocardites et ou des ischémies myocardiques, des dysrythmies et des insuffisances cardiaques gauches. Les dysfonctions ventriculaires gauches en général s'améliorent avec le temps contrairement aux infarctus du myocarde qui peuvent progresser et détériorer encore la fonction ventriculaire. Cependant, la distinction entre la dysfonction gauche associée à l'HSA et l'ischémie ou l'infarctus myocardique peut représenter un défi. Les anomalies échocardiographiques chez les patients avec HSA ont plus de chance d'être en relation avec un devenir neurologique pauvre qu'avec un devenir cardiaque pauvre. ${ }^{17}$

Les interactions médicamenteuses importantes comprennent les effets sur la pression artérielle et la poten- 
tialisation des anesthésiques volatils et des relaxants musculaires chez les patients recevant des bloqueurs calciques. ${ }^{18}$ Les anticonvulsivants, lorsque administrés durant plus d'une semaine, induisent une résistance aux relaxants musculaires non dépolarisants. ${ }^{19}$ Les patients recevant des antifibrinolytiques peuvent présenter des problèmes d'accès vasculaire, une tendance accrue aux thromboses veineuses profondes et une incidence accrue de vasospasme et d'hydrocéphalie. Les bloqueurs $\mathrm{H}_{2}$, spécialement la cimétidine, vont ralentir l'élimination de plusieurs agents anesthésiques et autres médicaments métabolisés par le foie. Les glucocorticoïdes peuvent contribuer à l'hyperglycémie, à l'hypertension, au saignement digestif, au débalancement électrolytique et à l'inhibition de l'axe surrénalo-hypothalamo-hypophysaire.

La différence entre la pression artérielle systémique et la PIC constitue la pression transmurale s'exerçant sur la paroi de l'anévrysme. Des augmentations aiguës de la pression transmurale, soit par augmentation aiguë de la pression artérielle ou soit par réduction aiguë de la PIC, prédisposent à la rerupture de l'anévrysme. L'hypertension extrême en période préopératoire doit être traitée avec beaucoup de précaution car elle peut être nécessaire à une perfusion cérébrale adéquate. $\mathrm{Si}$ on doit la traiter, on peut utiliser en le titrant soigneusement un agent comme le labétalol, un antagoniste combiné des récepteurs alpha et beta adrénergiques. Le labétalol semble ne pas avoir d'effet sur le flot sanguin cérébral. ${ }^{20}$ Comme alternative on peut utiliser un bloqueur calcique, la nicardipine. ${ }^{21}$

Les patients présentant un état de conscience altéré ne devraient probablement pas recevoir de prémédication anxiolytique mais les patients en meilleur état peuvent probablement recevoir une benzodiazépine à dose réduite.

\section{Induction de l'anesthésie}

Dans notre pratique, tous les patients subissant une crâniotomie sont monitorés de la façon suivante : saturomètre, ECG à 5 électrodes, capnographe, thermomètre, sonde urinaire, stimulateur nerveux périphérique et mesure directe de la pression arténielle, en général à partir de la radiale.

Les patients peuvent avoir reçu des traitements prophylactiques contre le vasospasme, incluant des bloqueurs calciques et la triple thérapie hémodilution, hypertension, hypervolémie (HHH). ${ }^{22}$ Il est donc important de monitorer l'état de la volémie. Il est important à ce moment de souligner qu'il n'y a aucune évidence convaincante que le fait d'augmenter le débit cardiaque améliore directement le flot sanguin cérébral (CBF), aussi longtemps que la pression de perfusion cérébrale (OPPC) est adéquate. ${ }^{23} \mathrm{C}$ 'est le gradient de pression à travers un lit vasculaire et sa résistance qui détermine le flot capillaire et la perfusion tissulaire. Dans l'insuffisance cardiaque congestive chronique, le fait de traiter l'état de bas débit améliore le CBF probablement en diminuant la pression veineuse centrale élevée et, de ce fait, la pression veineuse cérébrale. ${ }^{24} \mathrm{De}$ plus, les états de bas débit peuvent aggraver l'ischémie cérébrale. La stimulation du système nerveux sympathique augmente la résistance vasculaire cérébrale en produisant une vasoconstriction des artères proximales de conductance. ${ }^{25}$

De toute façon, le fait de maintenir un volume intravasculaire relativement élevé (remplissage) est, par comparaison à des contrôles historiques, associé à un meilleur pronostic. ${ }^{26} \mathrm{Le}$ monitorage des pressions vasculaires centrales peut être utilisé chez les patients qui ont un état cardiovasculaire compromis ou qui ont un état clinique pauvre. Le remplissage peut être réalisé concommittemment à l'utilisation d'inotropes ou de médicaments qui augmentent la post charge. Le monitorage des pressions de remplissage cardiaque peut minimiser les complications telles que la surcharge, l'hyponatrémie dilutionnelle, l'exacerbation de l'œdème cérébral, l'insuffisance cardiaque congestive et l'œdème pulmonaire.

Il n'y a pas de consensus évident quant à l'utilisation des moniteurs électrophysiologiques comme l'EEG et les potentiels évoqués, alors que dans les situations d'hypotension délibérée ou d'occlusion de l'artère temporale, leur utilisation est amplement justifiée. De plus, l'EEG peut être uitilisé pour titrer des médicaments comme le thiopental jusqu'à un stade facile à utiliser en clinique, celui des pauses électriques («burst suppression»). Cependant, ce stade ne doit pas être interprété comme indiquant une dose de protection maximale de ces médicaments.

Une hypertension aiguë à l'induction peut favoriser le resaignement. La rupture survenant au cours de l'induction et de l'intubation survient chez environ 1 à $2 \%$ des patients selon les études. ${ }^{27} \mathrm{La}$ rerupture au moment de l'induction est associée avec un pronostic nettement plus pauvre qu'une rupture peropératoire, ${ }^{27-29}$ probablement à cause de la capacité restreinte de l'hémorragie récente à s'expandre compte tenu des adhérences et du caillot préexistant. Une hypotension prolongée doit être évitée chez tout patient porteur de lésion cérébrale à moins que le risque soit contrebalancée par un bénéfice marqué comme celui d'avoir un accès plus facile au collet d'un anévrysme durant le clipping.

Le choix du relaxant musculaire pour l'intubation doit être basé sur des considérations de gestion des voies aériennes. La succinylcholine est contre-indiquée chez les patients présentant des déficits moteurs 
récents ou progressifs; si elle est utilisée, les augmentations de PIC peuvent être émousées par une précurarisation. De façon générale, nous préférons utiliser des non-dépolarisants comme le vécuronium.

Il n'y a pas d'évidence marquée qu'aucun agent d'induction n'offre un avantage sur un autre quant à la protection cérébrale; le choix devrait donc être dicté par des considérations hémodynamiques.

Une hyperventilation rapide et profonde peut diminuer la PIC avec crâne intact et peut augmenter la pression transmurale à travers la paroi d'un anévrysme. Parce que la vasoconstriction induite par l'hypocapnie peut menacer des zones où la pression de perfusion est déjà près du seuil ischémique, une $\mathrm{PaCO}_{2}$ de l'ordre de 32 à $35 \mathrm{mmHg}$ apparaît raisonnable, à moins qu'il n'existe un problème spécifique de relâchement cérébral ou d'exposition.

\section{Maintien de l'anesthésie}

Il n'y a pas de technique de maintien de l'anesthésie qui soit clairement supérieure aux autres. Le choix de l'agent doit respecter les buts énoncés dans la première section. Des concentrations inspirées élevées risquent d'entraîner un gonflement cérébral. Si le relâchement cérébral devient un problème durant l'opération, il faut toujours éliminer comme cause une concentration élevée d'agent halogéné. Des concentrations faibles des agents halogénés ne devraient pas affecter l'interprétabilité de l'EEG ou des potentiels évoqués. L'utilisation des agents, avec lesquels l'anesthésiste est le plus familier pour atteindre les buts de protection cérébrale non pharmacologique, est probablement l'approche la plus rationnelle dans le choix des agents. En principe, les médicaments avec demi-vie courte et disparition rapide des effets sont souhaitables pour permettre de titrer l'effet et d'obtenir un réveil rapide.

Les nouveaux agents incluent le desflurane qui est relativement insoluble en comparaison avec les agents plus anciens, ${ }^{30}$ mais qui peut être associé à des augmentations de pression significatives durant l'induction. ${ }^{31}$ Le propofol peut être utilisé comme composante d'une technique intraveineuse complète (TIVA). ${ }^{22}$ Le remifentanil, un nouvel opiacé ayant une demi-vie très courte, indépendante de la durée de la perfusion a récemment été introduit en pratique clinique et on en fait actuellement l'évaluation pour la neuroanesthésie. ${ }^{32,33}$ Le fait de tousser ou de bouger durant la microchirurgie peut avoir des effets dévastateurs: la surveillance méticuleuse de la curarisation est de règle. Même si occasionnellement la ventilation spontanée est conservée pour monitorer la fonction du tronc cérébral, ${ }^{34}$ c'est la ventilation mécanique qui est la norme.

Lorsqu'on approche de l'anévysme, et avant l'application de la clip, des mesures peuvent être prises pour diminuer la tension de l'anévrysme pour que le chirurgien puisse le manipuler délicatement avec un risque réduit de rupture. Pour réduire la tension dans l'anévrysme on peut diminuer la pression artérielle systémique ou le chirurgien peut placer une clip temporaire sur le vaisseau nourrissant l'anévrysme.

Jusqu'à récemment, l'hypotension délibérée était la règle durant le clippage d'anévrysme et était considérée comme un progrès majeur en neurochirurgie, améliorant le pronostic du traitement chirurgical des anévrysmes intracrâniens. ${ }^{35}$ Les préoccupations concernant le risque d'ischémie cérébrale périopératoire et d'infarcissement ont cependant conduit à l'abandon de cette technique dans plusieurs centres. ${ }^{36}$ D'autre part, avec une attention méticuleuse aux détails et l'utilisation des techniques modernes de monitorage cardiovasculaire et neurophysiologique, l'hypotension peut encore être indiquée chez certains patients choisis. Une enquête récente auprès de 41 centres nord-américains traitant des anévrysmes a montré que cette technique est encore urilisée par environ $48 \%$ des neuroanesthésistes. ${ }^{37}$

Même si l'utilisation de l'hypertension délibérée a été abondamment rapportée durant l'occlusion vasculaire temporaire pour clippage d'anévrysme, ${ }^{38-42}$ les données sont ici encore plus du domaine de l'anecdote ou de l'observation de cas.

Récemment, l'occlusion temporaire du vaisseau nourricier de l'anévrysme est devenue la méthode la plus fréquemment utilisée pour diminuer la tension dans l'anévrysme. Cette occlusion vasculaire temporaire a beaucoup de chances d'être distale au polygone de Willis, ce qui rend les chances de perfusion collatérale adéquate plus limitées.

Lors du clippage temporaire, la pression artérielle est en général gardée au moins $10-20 \%$ au-dessus des niveaux normaux du patient éveillé de façon à diminuer les chances d'insuffisance du flot collatéral. La phényléphrine, un agoniste alpha-adrénergique est l'agent le plus fréquemment utilisé pour cette hypertension délibérée. L'occlusion temporaire peut entrainer une ischémie cérébrale et un infarcissement, en dépit du maintien d'une pression de perfusion collatérale augmentée. ${ }^{43}$

L'anesthésique neuroprotecteur le plus fréquemment utilisé (et le mieux justifié) est le thiopental. L'évidence en faveur d'un effet protecteur est plus faible pour le propofol et l'étomidate. Immédiatement avant l'application de la clip temporaire, le thiopental peut être administré en quantité suffisante pour occasionner des pauses électriques marquées ou un pattern isoélectrique à l'EEG. En limitant la dose à celle qui entraîne des pauses électriques, on peut conserver la capacité de détecter une ischémie cérébrale par les 
changements progressifs à l'EEG. Même si l'utilité de l'analyse de l'EEG durant la chirurgie de l'anévrysme a été mise en doute à cause d'une sensibilité faible, le nombre de faux négatifs peut être diminué par l'utilisation d'électrodes corticales qui explorent la région la plus à risque. ${ }^{40}$ On peut aussi utiliser une autre voie, celle des potentiels évoqués, pour la détection de l'ischémie. ${ }^{44}$

Le thiopental à doses élevées a été considéré comme un dépresseur myocardique puissant. Des études récentes ont cependant montré que la fonction myocardique de même que la pression artérielle étaient bien maintenues si le patient était bien hydraté. ${ }^{45}$ Cependant, pour les patients présentant une dysfonction myocardique significative ou une maladie cardiaque ischémique sévère, l'étomidate pourrait être l'agent de choix.

Une fois l'anévrysme clippé, un traitement plus agressif pour prévenir ou traiter le vasospasme peut être débuté: le volume intravasculaire est accru et la pression artérielle est augmentée dans la zone normale-haute par le remplissage et/ou par l'administration de vasopresseurs. Le saignement n'est en général pas remplacé à moins que la chute de l'hématocrite ne mette en péril le transport d'oxygène.

\section{Désastre}

Que l'hypotension délibérée soit planifiée ou non, des agents hypotenseurs doivent être immédiatement disponibles en cas de rupture anévrysmale peropératoire. Le pronostic à la suite d'un saignement peropératoire semble résider dans la rapidité à assurer l'hémostase. La pression artérielle moyenne peut devoir être rapidement abaissée à 40-50 $\mathrm{mmHg}$ pour diminuer le saignement et faciliter l'exposition chirurgicale de façon à pouvoir contrôler l'anévrysme et son vaisseau nourricier.

La plupart des chirurgiens s'assurent, de routine, du «contrôle proximal» du vaisseau nourricier de l'anévrysme soit directement dans le champ opératoire soit par une dissection cervicale de la carotide interne. En dépit de ces précautions, il peut être nécessaire de comprimer manuellement la carotide commune homolatérale dans certains cas. Il est donc prudent de s'assurer que cette région anatomique demeure accessible après le positionnement du patient.

Au moment d'une hémorragie incontrôlée les chirurgiens peuvent devoir placer à l'aveugle des clips pour tenter d'arrêter l'hémorragie. Dans cette situation, un traitement avec des barbituriques pourrait être indiqué et pourrait être utilisé comme un moyen, ou comme un ajout, pour réduire temporairement la pression artérielle de façon légère à modérée jusqu'à ce que le saignement soit sous contrôle. Toutefois, le clinicien devrait utiliser tous les moyens à sa disposi- tion avec lesquels il est à l'aise et qui sont aptes à diminuer très rapidement la pression artérielle, tel que la situation clinique l'exige.

\section{Traitement endovasculaire}

Survol

Des anomalies du système cérébrovasculaire sont traitées de plus en plus souvent avec une approche endovasculaire. La neuroradiologie interventionnelle (NRI) peut se définir grossièrement comme le traitement des maladies du système nerveux central (SNC) par accès endovasculaire dans le but d'aller livrer sur place des agents thérapeutiques, que ce soit des médicaments ou des prothèses. ${ }^{46}$ Cette spécialité est un hybride de la neurochirurgie traditionnelle et de la neuroradiologie, certains aspects chevauchant aussi la chirurgie de la tête et du cou.

Les trois fonctions primaires de l'anesthésiste en salle de NRI sont 1-de garantir la stabilité physiologique et l'immobilité du patient 2-de manipuler la pression artérielle systémique selon les besoins de la procédure 3-de fournir les soins d'urgence en cas de complications catastrophiques.

Plusieurs des risques encourus dans cette nouvelle arène sont les mêmes que ceux encourus lors des interventions traditionnelles de neurochirurgie ( $p g$ rupture anévrysmale ou ischémie cérébrale par occlusion vasculaire) et les manipulations par l'anesthésiste de l'hémodynamie systémique ou cérébrale sont les mêmes, vg hypertension ou hypotension délibérées. Même si plusieurs des réponses et des risques sont pour la plupart identiques, il existe plusieurs différences importantes dans l'environnement de travail.

De façon historique, les pionniers de la NRI ont traité leurs patients adultes avec une sédation intraveineuse légère et un monitorage rudimentaire. Cependant, dans plusieurs centres la couverture anesthésique est devenue une norme de pratique. À mesure que la complexité des procédures et l'éventail des patients augmente, la distinction entre la suite d'angiographie interventionnelle et la salle d'opération va s'estomper. Pour une discussion plus détaillée des indications et de l'expertise nécessaire, le lecteur est référé à un autre texte. ${ }^{47}$

\section{Traitement des anévrysmes cérébraux}

La plupart des anévrysmes peuvent être oblitérés de façon chirurgicale tout en préservant le vaisseau nourricier. Cependant, il persiste des difficultés dans le traitement de certains types d'anévrysmes, par exemple les anévrysmes géants et les anévrysmes fusiformes. Les deux approches de base lors de traitement en NRI sont l'occlusion des artères nourricières proximales et l'oblitération du sac anévrysmal. 
Pour certains anévrysmes géants, une oblitération par ballon de la carotide cervicale peut être réalisée avec pontage extracrânien-intracrânien subséquent. Un protocole comportant un essai de test d'occlusion avec monitorage physiologique peut être utile pour prédire quels patients ont une réserve cérébrovasculaire limite.

Le sac anévrysmal peut être oblitéré avec des ballons et des serpentins. La plus nouvelle forme de traitement des anévrysmes est le «Guglielmi Detachable Coil» (GDC). ${ }^{49}$ Il s'agit d'un serpentin de platine de longueur variée et d'allure un peu fantaisiste. Il est attaché à une broche guide d'acier inoxydable. Le serpentin est introduit via un cathéter suprasélectif dans le sac anévrysmal où il est libéré en faisant passer un courant électrique dans la broche guide, qui se détache du serpentin en platine par électrolyse, laissant ce dernier enroulé dans le sac. Ces procédures, posant un besoin moindre de suivi continu neurologique, sont fréquemment réalisées sous anesthésie générale avec intubation endotrachéale.

L'anesthésiste devrait être prêt en tout temps pour une rupture anévrysmale et une HSA aiguë, ou par rupture spontanée d'un sac fragile ou par bris de la paroi de l'anévrysme durant les manipulations vasculaires. Présentement on n'est pas aussi certain de l'isolement complet de la lésion de la circulation après l'oblitération par serpentin qu'après l'application chirurgicale d'une clip. Il peut persister des zones du dôme de l'anévrysme qui demeurent en contact avec la colonne de sang artériel. Il est donc essentiel de s'assurer d'un contrôle méticuleux de la pression artérielle après la procédure. Comme la neuroradiologie interventionnelle progresse beaucoup plus rapidement que la microchirurgie ouverte, la fréquence relative d'utilisation du clippage et de l'embolisation pourrait changer.

\section{Traitement $d u$ vasospasme secondaire}

à une HSA anévrysmale

Un vasospasme symptomatique, résistant à l'hypertension délibérée et à l'expansion volémique, peut dans certains cas être traité par voie endovasculaire. Dans les gros vaisseaux de conductance proximaux (habituellement la carotide interne, la cérébrale antérieure ou moyenne), l'angioplastie par ballon peut être considérée. ${ }^{50}$ L'angioplastie est en général réservée aux patients qui ont déjà été traités par clippage chirurgical de la lésion symptomatique (par peur de rerupture) et chez lesquels des essais de traitement médical de l'ischémie symptomatique ont échoué.

Le traitement endovasculaire a avantage à être fait précocément lors d'une ischémie symptomatique pour éviter de transformer un infarcissement non hémor- ragique en un hémorragique. Un cathéter ballon est positionné sous fluoroscopie dans le segment spastique et est gonflé de façon à distendre mécaniquement cet endroit rétréci.

Une autre approche du vasospasme est l'utilisation de moyens pharmacologiques pour dilater le segment vasospastique. Une administration intraartérielle suprasélective de papavérine s'est avérée efficace chez certains patients. ${ }^{51}$

\section{Remerciements}

L'auteur remercie Joyce Ouchi, E. Ornstein et Z. Shenkman pour leur aide dans la préparation de ce manuscrit.

\section{Références}

(Voir page R22) 